\title{
The effect of cavity disinfectants on the micro-shear bond strength of dentin adhesives
}

\author{
Dina Wafik Elkassas ${ }^{1}$, Elham Mostafa Fawzi ${ }^{2}$, Ahmed El Zohairy ${ }^{2}$
}

Correspondence: Dr. Dina Wafik Elkassas

Email: dinaelkassas2000@yahoo.com

\author{
'Department of Operative Dentistry, Faculty of Oral and \\ Dental Medicine, Misr International University, Cairo, \\ Egypt, \\ ${ }^{2}$ Department of Operative Dentistry, Faculty of Oral and \\ Dental Medicine, Cairo University, Cairo, Egypt
}

\section{ABSTRACT}

Objectives: This study was carried out to examine the effect of application of four different disinfecting agents on the micro-shear bond strength ( $\mu$-SBS) of an etch-and-rinse and self-etch adhesive systems. Materials and Methods: One hundred flat dentin surfaces of human molars were produced by wet grinding the buccal surfaces. Specimens were randomly assigned to five groups according to the disinfectant used: Group I: Control (no disinfectant); Group II: 5.25\% sodium hypochlorite based; Group III: 2\% chlorhexidine based (Consepsis), Group IV: 0.1\% benzalkoniumchloride based (Tubulicid red) and Group V: 3\% doxycycline based (Biopure, MTAD). Specimens were bonded using either Adper Single Bond 2 or Clearfil $\mathrm{S}^{3}$ Bond, which were employed according to the manufacturer's instructions. Resin composite microcylinders were bonded using Tygon ${ }^{\circledR}$ tubes for $\mu$-SBS testing. The modes of failure were noted after visual examination using a binocular stereomicroscope at $\times 25$ magnification. Failures were classified as adhesive, or mixed. $\mu$-SBS results were analyzed using two-way ANOVA followed by Tukey's post-hoc test. Results: Dentin disinfectants tested significantly negated the bonding of Adper Single bond 2 and the groups were ranked; Group I > Group V = Group IV > Group II = Group III, meanwhile they enhanced significantly the $\mu$-SBS values upon using Clearfil $\mathrm{S}^{3}$ Bond and were ranked; Group II $>$ Group III = Group IV = Group V > Group I. Most failures were adhesive with the Adper single bond adhesive system. Mixed modes of failure were evident with Clearfil $\mathrm{S}^{3}$ bond. Conclusions: The disinfectants tested should not be used with Adper Single Bond 2 when applied before the etching step, However they could be used safely prior to bonding with Clearfil $\mathrm{S}^{3}$ Bond.

Key words: Benzalkonium chloride, chlorhexidine, doxycycline, sodium hypochlorite

\section{INTRODUCTION}

Bacterial activity has proved to be the main causative factor for placement and replacement of restorations. ${ }^{[1]}$ It wasconfirmed histologically that fermentative organisms remained viable under non-antispetic restorations for as long as 139 days and that only a portion of the tooth is sterile after termination of routine cavity preparation. ${ }^{[2]}$ Furthermore, bacteria present in the smear layer can multiply, allowing their toxins and degradation products to diffuse to the pulp resulting in irritation and inflammation. ${ }^{[3]}$ Bacterial penetration along the interface or nanoleakage is another concern, which was found to cause recurrence of caries. ${ }^{[4]}$
As infection beneath the restoration is considered a great threat to the pulp, the concept of toileting of the cavity is gaining wider acceptance with a variety of commercially available dentin disinfectants launched into the market. These dentin disinfectants are (amongst others) chlorhexidine (CHX), benzalkonium chloride, iodine/copper sulfate, sodium hypochlorite (NaOCL) and/or antibiotic based. The ideal dentin disinfectant should combine the possession of a potent antimicrobial action and should not interfere with the bonding of the subsequently applied adhesive system. Furthermore, it should enhance the durability of the bond through the inhibition of the matrix derived enzyme (matrix-metalloprotease). ${ }^{[5]}$

\footnotetext{
How to cite this article: Elkassas DW, Fawzi EM, El Zohairy A. The effect of cavity disinfectants on the micro-shear bond strength of dentin adhesives. Eur J Dent 2014;8:184-90.

Copyright @ 2014 Dental Investigations Society. DOI: $10.4103 / 1305-7456.130596$
} 
The dental literature shows the association of dentin disinfectant application and bonding of subsequent applied adhesive system to be a controversial issue. Some authors showed that the disinfectant application negated the bonding process. ${ }^{[1,6,7]}$ Others showed that it did not impair the bonding process. ${ }^{[8-11]}$ Although others found that it enhanced the bonding process. ${ }^{[12,13]}$ Brackett et al. ${ }^{[14]}$ and Campos et al., ${ }^{[15]}$ in their study have reported that the application of the dentin disinfectant didn't affect the initial bond strength, however it promoted the stability of the bond after 6 months service in vivo in Bracket's et al. study and in vitro under simulated pulpal pressure in Campos' et al., study. Thus, the selection of the disinfectant compatible with the bonding system is of great importance as any positive benefits would be negated if the antimicrobial action deteriorated the bonding efficacy.

On the search on the most appropriate disinfectant to be applied prior to both etch-and-rinse and self-etch adhesive systems, this study was carried out to clarify the behavior of each of these antibacterial agents on the micro-shear bond strength ( $\mu$-SBS) of both etch-and-rinse and self-etch adhesive systems. The null hypothesis examined first; there is no differences in the $\mu$-SBS between both etch-and-rinse and self-etch adhesives, second: there is no difference in the $\mu$-SBS between control and differently disinfected dentin surfaces with both etch-and-rinse and self-etch adhesive systems.

\section{MATERIALS AND METHODS}

\section{Materials}

This study evaluated the effect of four contemporary dentin disinfectants; $5.25 \%$ NaOCL based; $2 \%$ CHX based (Consepsis, CHX), $0.1 \%$ benzalkonium chloride based (Tubulicid red, TR) and $3 \%$ doxycycline based (Biopure, MTAD) on the $\mu$-SBS of both etch-and-rinse (Adper Single Bond 2) and self-etch (Clearfil $S^{3}$ Bond) adhesive systems. Materials composition, manufacturer and lot number are presented in Table 1.

\section{Specimen preparation}

One hundred sound human molars recently extracted and stored in physiologic saline at $4^{\circ} \mathrm{C}$ for no more than 2 weeks, were used in the present study. After removal of the root portion, the molars, excluding the buccal surface, were embedded in self-curing acrylic resin (Rapid Repair, DeguDent GmbH, Hanau, Germany) by using a specially fabricated cuboidal Teflon mold $(3 \mathrm{~cm} \times 2 \mathrm{~cm} \times 1.3 \mathrm{~cm})$. The buccal surfaces of the embedded molars were ground on a water cooled mechanical grinder (TF250, JeanWirtz, Düsseldorf, Germany) by using 180-grit abrasive paper to obtain flat superficial dentin surfaces with a clinically relevant smear layer. ${ }^{[16]}$

The specimens were randomly assigned to five groups according to the disinfectant used:
Group I:
No disinfectant (control)
Group II:
$\mathrm{NaOCl}$
Group III:
$\mathrm{CHX}$
Group IV:
TR
Group V:
MTAD.

The disinfectants were applied for $60 \mathrm{~s}$ then rinsed. Each group was further divided into two subgroups

\begin{tabular}{|c|c|c|}
\hline Material used & Composition & Manufacturer and lot number \\
\hline \multicolumn{3}{|l|}{ Dentin disinfectant } \\
\hline $\mathrm{NaOCl}$ & $5.25 \% \mathrm{NaOCl}$ & Clorox Co, Cairo, Egypt (KPE7-07) \\
\hline Consepsis (CHX) & $2 \% \mathrm{CHX}$ gluconate & Ultradent (u015) \\
\hline Tubulicid red (TR) & $\begin{array}{l}0.1 \% \text { benzalkonium chloride, } 0.2 \% \\
\text { EDTA, } 1 \% \text { sodium fluoride }\end{array}$ & $\begin{array}{l}\text { Global Dental Products, North } \\
\text { Bellimore, NY. (310107 1009) }\end{array}$ \\
\hline Biopure (MTAD) & $\begin{array}{l}\text { Tetracycline isomer (doxycycline) } 3 \% \text {, citric } \\
\text { acid } 4.25 \% \text {, detergent (Tween } 80 \text { ) } 0.5 \%\end{array}$ & Dentsply, Tulsa, USA (060406) \\
\hline \multicolumn{3}{|l|}{ Adhesive systems } \\
\hline Clearfil $S^{3}$ bond & $\begin{array}{l}\text { MDP (monomer), BisGMA, HEMA, dl-camph- } \\
\text { orquinone, ethyl alcohol, water, silanated colloidal silica }\end{array}$ & Kuraray, Japan. (00007B) \\
\hline Adper single bond 2 & Bis-GMA, HEMA, dimethacrylates, ethanol, water & 3M ESPE, St Paul MN, USA (7KF) \\
\hline \multicolumn{3}{|l|}{ Etchant } \\
\hline Scotchbond & $35 \%$ phosphoric acid & 3M ESPE, St. Paul MN, USA (7JC) \\
\hline \multicolumn{3}{|l|}{ Resin composite } \\
\hline Clearfil APX & $\begin{array}{l}\text { Micro hybrid composite filled with barium glass } \\
\text { particles }\end{array}$ & Kuraray, Japan. (01170A) \\
\hline
\end{tabular}


according to the adhesive system employed. In the first sub-group; the etch-and-rinse adhesive system, Adper Single Bond 2, was used. The specimens were etched for $15 \mathrm{~s}$ with the phosphoric acid etchant followed by rinsing for $10 \mathrm{~s}$ then blotting excess water using a mini-sponge. Immediately after blotting, two consecutive coats of the bonding system was attempted for $15 \mathrm{~s}$ with gentle agitation using a fully saturated application followed by gentle air thinning for $5 \mathrm{~s}$ to evaporate the solvent. In the second sub-group; the self-etching adhesive system, Clearfil $\mathrm{S}^{3}$ Bond, was applied according to manufacturer's instructions which were the generous application of the bonding system for $20 \mathrm{~s}$ followed by drying with high pressure air flow for approximately $5 \mathrm{~s}$.

Irises were cut from Tygon ${ }^{\circledR}$ tubing (R-3603, Norton Performance Plastic Co., Cleveland, USA) with an internal diameter of $0.8 \mathrm{~mm}$ and a height of $0.5 \mathrm{~mm}$. Two irises were mounted on the dentin surface to restrict the bonding area. Light curing of the bonding resin was attempted for $10 \mathrm{~s}$ using Elipar II light curing unit (3M ESPE, St. Paul, MN, USA). Resin composite, Clearfil APX; shade A2, was packed into the cylinder lumen and a plastic matrix strip was placed over the resin composite and gently pressed flat and light-cured for $40 \mathrm{~s}$. Using a blade, the Tygon tubes were removed after one hour storage at room temperature. This resulted in small cylinders of resin, approximately $0.8 \mathrm{~mm}$ in diameter and $0.5 \mathrm{~mm}$ in height bonded to the surface.

\section{Micro-shear bond strength ( $\mu-S B S)$ testing}

After storage in distilled water for $24 \mathrm{~h}$ their $\mu$-SBSs were measured using a universal testing machine (Lloyd Instruments Ltd., Fareham UK). A wire of $0.2 \mathrm{~mm}$ diameter was looped around the resin composite cylinder, making contact through half its circumference and was gently held flush against the resin-dentin interface. The resin-dentin interface, the wire loop and the center of the load-cell were aligned as straight as possible to ensure the correct application of the shear force. Shear force was applied to each specimen at a cross-head speed of $0.5 \mathrm{~mm} / \mathrm{min}$ until failure occurred. The two measured bond strength values obtained from each specimen were averaged to obtain one reading from each specimen $(n=10)$. Regression model with two-way analysis of variance (ANOVA) was used to test the significance for the effect of bonding system and disinfectant and their interactions. Tukey's post-hoc test was used for pair-wise comparison between the means when ANOVA test is significant. The significance level was set at $P \leq 0.05$. Statistical analysis was carried out using the SPSS 14.0 software (Statistical Package for Scientific Studies Inc. Chicago, IL, USA.).

After measuring the bond strength, each specimen was examined visually using a binocular stereomicroscope (Nilson SMZ-10-Japan) at $\times 25$ magnification to determine its mode of fracture. Failure modes were classified as Adhesive: where the fracture site was located between the adhesive and the dentin, or mixed: Where the fracture site included both adhesive failure at the interface and cohesive failure within the resin composite. The percentage of the failure modes was calculated.

\section{RESULTS}

Regression model analysis for different variables is presented in Table 2 . The mean $\mu$-SBS values and their respective standard deviations for the different groups are presented in Tables 3. Results revealed that the bonding system had a statistically significant effect on the mean values whereas the disinfectant had no statistical significant effect on the mean. The interaction between the two variables had an effect on the mean values [Table 2].

In general, use of disinfectants increased the bond strength when Clearfil $\mathrm{S}^{3}$ bond was used compared with the control specimens. $\mathrm{NaOCl}$ prior to the use of Clearfil $\mathrm{S}^{3}$ bond recorded the highest mean bond strength followed by the TR, CHX and MTAD.

This is contrary to the use of disinfectants with Adper Single bond 2 which led to the decrease of the bond [Table 3]. However, a statistical significant difference was found between the different disinfectants. CHX and MTAD in conjunction with Adper Single bond 2 recorded values that were lower than the control specimens bonded with Adper Single bond 2 only. TR and $\mathrm{NaOCl}$ recorded the least bond strength values when bonded with Adper Single bond 2.

The percentages of the fracture modes observed with all tested groups are presented in Table 4 . The predominant mode of failure with Adper Single bond 2 adhesive system groups was adhesive. The Clearfil $\mathrm{S}^{3}$ bond adhesive system groups showed mixed mode of failure, with the higher percentage with $\mathrm{NaOCl}$.

\section{DISCUSSION}

In the present study assessment the effect of application of four different disinfecting agents on bond strength 


\begin{tabular}{|c|c|c|c|c|c|}
\hline Source & $\begin{array}{l}\text { Sum of } \\
\text { squares }\end{array}$ & df & $\begin{array}{l}\text { Mean } \\
\text { square }\end{array}$ & $F$ & $P$ \\
\hline Corrected model & 2013.905 & 9 & 223.767 & 8.947 & $<0.001^{* *}$ \\
\hline Bonding system & 1471.275 & 1 & 1471.275 & 58.827 & $<0.001^{* *}$ \\
\hline Disinfectant & 67.394 & 4 & 16.842 & 0.673 & 0.612 \\
\hline $\begin{array}{l}\text { Bonding system } \times \\
\text { disinfectant }\end{array}$ & 448.394 & 4 & 112.098 & 4.482 & $0.002^{\star *}$ \\
\hline
\end{tabular}

**Significant at $P \leq 0.05$, df: Degree of freedom

Table 3: Mean and standard deviations of micro-shear strength values in $\mathrm{MPa}$ of all tested groups

\begin{tabular}{lcc}
\hline \multirow{2}{*}{$\begin{array}{l}\text { Disinfectant } \\
\text { (group) }\end{array}$} & \multicolumn{2}{c}{ Adhesive } \\
\cline { 2 - 3 } & Clearfil S ${ }^{3}$ bond & Adper single bond 2 \\
\hline I: Control & $14.58 \pm 4.7^{\mathrm{c}}$ & $13 \pm 4.5^{\mathrm{c}}$ \\
II: $\mathrm{NaOCI}$ & $20.46 \pm 5.9^{\mathrm{a}}$ & $6.46 \pm 2.1^{\mathrm{e}}$ \\
III: TR & $16.98 \pm 3.5^{\mathrm{b}}$ & $6.14 \pm 3.5^{\mathrm{e}}$ \\
IV: $\mathrm{CHX}$ & $16.03 \pm 5.6^{\mathrm{b}}$ & $9.3 \pm 4.6^{\mathrm{d}}$ \\
V: MTAD & $16.76 \pm 5.2^{\mathrm{b}}$ & $10.65 \pm 2.8^{\mathrm{d}}$
\end{tabular}

Subgroups that are statistically similar $(P>0.05)$ are indicated by the same letter. NaOCl: Sodium hypochlorite, TR: Tubulicid red, CHX: Chlorhexidine, MTAD: Mixture of Tetracycline isomer, citric acid and detergent

\begin{tabular}{|c|c|c|c|c|}
\hline \multirow{2}{*}{$\begin{array}{l}\text { Adhesive } \\
\text { disinfectant } \\
\text { used (group) }\end{array}$} & \multicolumn{2}{|c|}{ Clearfil $\mathrm{S}^{3}$ bond } & \multicolumn{2}{|c|}{ Adper single bond 2} \\
\hline & Adhesive & Mixed & Adhesive & Mixed \\
\hline I: Control & 80 & 20 & 90 & 10 \\
\hline II: $\mathrm{NaOCl}$ & 60 & 40 & 100 & 0 \\
\hline III: TR & 75 & 25 & 100 & 0 \\
\hline IV: CHX & 70 & 30 & 100 & 0 \\
\hline V: MTAD & 75 & 25 & 95 & 5 \\
\hline
\end{tabular}

NaOCl: Sodium hypochlorite, TR: Tubulicid red, CHX: Chlorhexidine,

MTAD: Mixture of Tetracycline isomer, citric acid and detergent

of an etch-and-rinse and self-etch adhesive systems was carried out using $\mu$-SBS testing. Micro-shear test generates less stress or damage during preparation of specimens compared to the micro-tensile alternative. ${ }^{[17]}$ In addition, this simple test allows conservation of teeth with regional and depth profiling of a variety of substrates. ${ }^{[18]}$

The results of this in vitro study support the rejection of the null hypothesis that there is no difference in the $\mu$-SBS between the self-etch and etch and rinse adhesives when bonded to superficial dentin pretreated with various dentin disinfectants and extend to support the second null hypothesis that the bond strength is not affected by the use of disinfectants.

The self-etching, Clearfil $S^{3}$ Bond, showed no statistically significant difference compared to the etch-and-rinse, Adper Single Bond 2, in the control group and significantly higher bond strength in all the rest groups. Furthermore higher percentage of mixed mode of failure was depicted in Clearfil $S^{3}$ Bond groups. Clearfil $\mathrm{S}^{3}$ Bond is a mild self- etch adhesive with a $\mathrm{pH} \geq 2.7,{ }^{[19]}$ thus the hybrid layer is comprised of partially naked collagen fibrils, allowing the remaining hydroxyapatite crystals to act as good candidates for additional intermolecular interaction with the 10-methacryloyloxydecyl dihydrogen phosphate (MDP) monomer creating a chemical bond, allowing for the two-fold bonding mechanism; micromechanical and chemical bonding. ${ }^{[20,21]}$ Thus deduction in the bonding efficacy resulting from the reduction in the micromechanical interlocking capacity was compensated with the chemical bonding capability. In addition, the calcium salt created by the phosphate monomer is highly insoluble, allowing more stable and intense molecular adhesion, according to the adhesion-decalcification concept. ${ }^{[20-22]}$ Accordingly, the superior bonding performance of functional monomers might be reflected in their actual capacity for adhesive bonding to dentin.

$\mathrm{NaOCl}$ is one of the most commonly used cavity disinfectant in clinical practice, not only to its well-known antibacterial action, but also to its wettability property. ${ }^{[23]} \mathrm{NaOCl}$ surface pretreatment enhanced the bond strength of self-etch adhesive Clearfil $\mathrm{S}^{3}$ bond. This findings correlates with the results of Fawzy et al., ${ }^{[2]}$ who reported that pretreatment the dentin surface with $\mathrm{NaOCl}$ significantly increased the bond strength of the self-etching adhesive, Adhes. This could be attributed to the non-specific proteolytic capability of $\mathrm{NaOCl}$ which can remove the organic components effectively at room temperature. ${ }^{[25]}$ Since the smear layer composition is similar to the originating tissue (50 volume \% mineral and 30 volume \% collagen), the application of the $\mathrm{NaOCl}$ over the smear layer covered dentin would eliminate its collagen phase resulting in reduction in the smear layer compactness. This property enhanced the bonding of the self-etching adhesive examined as it might have increased the diffusively of the acidic monomers, through water-filled channels between particles of smear layer enlarging them to reach and interact with the underlying dentin surface. As it is reported by several authors ${ }^{[26,27]}$ that the minimal aggressiveness of this ultra-mild self-etching adhesive makes it extremely sensitive in penetrating smear layers of different thickness and compactness. 
From a crystallographic view point, eliminating the organic component makes the dentin surface richer in hydroxyapatite crystals thus enhancing the chemical bonding component of this adhesive system. However, the results are in contrary with Ercan et al., ${ }^{[23]}$ and Santos et al., ${ }^{[28]}$ who reported that $\mathrm{NaOCl}$ negatively affected the bond strength of Clearfil SE bond, the difference in the methodology, dentin substrate and bonding material generation could be the reason for dissimilar results.

On the other hand, the use of $\mathrm{NaOCl}$ reduced the bond strength to the Adper Single bond 2 which could be due to the sensitivity of such adhesive system to the oxidizing effect of $\mathrm{NaOCl} .^{[29,30]}$ The results are again in contrary with Ercan et al., ${ }^{[23]}$ who found that $\mathrm{NaOCl}$ did not affect SBS of the etch and rinse adhesive, Prime and Bond NT.

TR is a benzalkonium chloride based dentin disinfectant. It also contians $0.2 \%$ ethylenediaminetetraacetic acid (EDTA) and 1\% sodium chloride. Benzalkonium chloride is a nitrogenous cationic surface-acting agent containing a quaternary ammonium group. It has three main uses; an antimicrobial agent, as a cationic surfactant and a matrix metalloprotease inhibitor. ${ }^{[31]}$ The results of the present study revealed that the use of TR enhanced the $\mu$-SBS of the self-etch adhesive, Clearfil $\mathrm{S}^{3}$, compared with the control group, yet it did not reach that obtained by $\mathrm{NaOCl}$. This could be attributed to its compositional constituent of EDTA, which might have led to the partial removal of the smear layer, ${ }^{[13]}$ which could have enhanced the interaction of the applied self-etch adhesive system with underlying dentin substrate.

In contrary, it negated the bonding of etch-and-rinse adhesive, as its compositional constituent of benzalkonium chloride and sodium fluoride might have been incorporated in the remaining part of smear layer increasing it resistance to phosphoric acid etching, thus hindering the permeation of Adper Single Bond 2 monomers.

This finding is in contrary with those of Sharma et al., ${ }^{[32]}$ whom found that TR negated the SBS of self-etching adhesive, Clearfil SE bond, whereas did not affect the bonding of the etch-and-rinse adhesive, Prime and Bond NT.

CHX is among the well-known antimicrobial agents and matrix metalloproteinase inhibitors. ${ }^{[1,2,10]}$ The results of the present study revealed that $\mathrm{CHX}$ pretreatment enhanced the bonding performance of the self-etch adhesive examined. This finding is in line with study by Pilo et al., ${ }^{[12]}$ who reported that pretreating the dentin surface with $\mathrm{CHX}$ improved the bond strength of self-etch adhesive systems.

Several theories can be hypothesized to explain the mode of action of CHX; first; the changes encountered in the smear layer. Scanning electron microscope examination by Meiers and Kresin ${ }^{[6]}$ showed that CHX modified the appearance of the smear layer by removal of the loose smear debris. This could have enhanced the penetration of the acidic monomers of the self-etch adhesive. Second; the strong positive ionic charge that ready binds to phosphate groups of dentin surfaces could have increased the surface energy of dentin, thus increasing dentin-wetting ability of primers. ${ }^{[8]}$ Furthermore, it could have enhanced the chemical bonding capacity of the MDP monomer. Third; this could be attributed to the possible stabilizing effect exerted on the smear layer turning it from a semi-permeable, loosely bound layer to a firmly bond layer, ${ }^{[6]}$ thus minimizing the convective and evaporative water fluxes from the underlying dentin, thus enhancing the bonding capacity of the self-etch adhesive.

On the other hand, using CHX before acid etching negated the bonding of the etch-and-rinse alternative. This is in agreement with Gürgan et al., ${ }^{[33]}$ who found that application of $\mathrm{CHX}$ before acid etching significantly reduced the bond strength. As any possible positive effect from its charge or composition would be negated by the etching and rinsing step. Furthermore that possible stabilizing effect which is considered pros for the self-etch adhesive is considered a con for the etch-and-rinse alternative, as the smear layer became resistant to the phosphoric acid etching.

However, this result is in contrary with Soares et al., ${ }^{[11]}$ and Brackett et al..$^{[14]}$ whom reported that using CHX with etch-and-rinse adhesives either enhance or not affect the bonding mechanism. This contrary could be due to the difference in the protocol of applications, as in their studies CHX was applied after the etching step.

MTAD is a doxycycline based disinfectant, it has a potent antimicrobial and a matrix metalloproteinase inhibitory action. ${ }^{[34]}$ MTAD is an acidic solution with a $\mathrm{pH}$ of 2.15. It contains both the doxycycline and citric acid, that remove the smear layer and demineralize 
the under lying dentin by a synergistic effect. The acidic doxycycline liberates calcium and phosphate ions, while the citric acid binds the calcium ions. ${ }^{[35]}$ Although the removal of the smear layer enhanced the bonding of the Clearfil $\mathrm{S}^{3}$ bond compared to the control group, it showed significantly lower bond strengths compared with $\mathrm{NaOCl}$ group. This could be attributed to its mild demineralization effect allowing less calcium ions to be available for chemical bonding.

However, the use of MTAD negatively affected the bonding of the etch-and-rinse adhesive, as its mild etching effect followed by the phosphoric acid etching may have led to increase the depth of demineralization which was not compatible with the depth of resin monomer infiltration. This result is in agreement with Stanislawczuk et al., ${ }^{[34]}$ who found that $2 \%$ doxycycline jeopardize the bond strength and quality of hybrid layer of the etch-and-rinse adhesive systems, Prime and Bond NT and Adper Single bond 2.

\section{CONCLUSION}

Under the limitation of this in vitro study it can be concluded that:

1. The self-etching adhesive, Clearfil $S^{3}$ Bond, provide prompt bonding to dentin treated with different disinfectants compared with, Adper Single Bond 2 , the etch-and-rinse adhesive alternative.

2. The use of the tested dentin disinfectants before the acid etching step negated the bonding performance of the tested etch-and-rinse adhesive.

\section{REFERENCES}

1. Meiers JC, Shook LW. Effect of disinfectants on the bond strength of composite to dentin. Am J Dent 1996;9:11-4.

2. Dalkilic EE, Arisu HD, Kivanc BH, Uctasli MB, Omurlu H. Effect of different disinfectant methods on the initial microtensile bond strength of a self-etch adhesive to dentin. Lasers Med Sci 2012;27:819-25.

3. Say EC, Koray F, Tarim B, Soyman M, Gülmez T. In vitro effect of cavity disinfectants on the bond strength of dentin bonding systems. Quintessence Int 2004;35:56-60.

4. Hiraishi N, Yiu CK, King NM, Tay FR. Effect of $2 \%$ chlorhexidine on dentin microtensile bond strengths and nanoleakage of luting cements. J Dent 2009;37:440-8.

5. Breschi L, Mazzoni A, Ruggeri A, Cadenaro M, Di Lenarda R, De Stefano Dorigo E. Dental adhesion review: Aging and stability of the bonded interface. Dent Mater 2008;24:90-101.

6. Meiers JC, Kresin JC. Cavity disinfectants and dentin bonding. Oper Dent 1996;21:153-9.

7. Tulunoglu O, Ayhan H, Olmez A, Bodur H. The effect of cavity disinfectants on microleakage in dentin bonding systems. J Clin Pediatr Dent 1998;22:299-305.

8. Perdigao J, Denehy GE, Swift EJ Jr. Effects of chlorhexidine on dentin surfaces and shear bond strengths. Am J Dent 1994;7:81-4.

9. Bocangel JS, Kraul AO, Vargas AG, Demarco FF, Matson E. Influence of disinfectant solutions on the tensile bond strength of a forth generation dentin bonding agent. Pesq Odontol Bras 2000;14:107-11.

10. de Castro FL, de Andrade MF, Duarte Júnior SL, Vaz LG, Ahid FJ. Effect of 2\% chlorhexidine on microtensile bond strength of composite to dentin. J Adhes Dent 2003;5:129-38.

11. Soares CJ, Pereira CA, Pereira JC, Santana FR, do Prado CJ. Effect of chlorhexidine application on microtensile bond strength to dentin. Oper Dent 2008;33:183-8.

12. Pilo R, Cardash HS, Oz-Ari B, Ben-Amar A. Effect of preliminary treatment of the dentin surface on the shear bond strength of resin composite to dentin. Oper Dent 2001;26:569-75.

13. Pappas M, Burns DR, Moon PC, Coffey JP. Influence of a 3-step tooth disinfection procedure on dentin bond strength. J Prosthet Dent 2005;93:545-50.

14. Brackett WW, Tay FR, Brackett MG, Dib A, Sword RJ, Pashley DH. The effect of chlorhexidine on dentin hybrid layers in vivo. Oper Dent 2007;32:107-11.

15. Campos EA, Correr GM, Leonardi DP, Barato-Filho F, Gonzaga CC, Zielak JC. Chlorhexidine diminishes the loss of bond strength over time under simulated pulpal pressure and thermo-mechanical stressing. J Dent 2009;37:108-14.

16. Yiu CK, King NM, Suh BI, Sharp LJ, Carvalho RM, Pashley DH, et al. Incompatibility of oxalate desensitizers with acidic, fluoride-containing total-etch adhesives. J Dent Res 2005;84:730-5.

17. Roeder L, Pereira PN, Yamamoto T, Ilie N, Armstrong S, Ferracane J. Spotlight on bond strength testing - Unraveling the complexities. Dent Mater 2011;27:1197-203.

18. Armstrong S, Geraldeli S, Maia R, Raposo LH, Soares CJ, Yamagawa J. Adhesion to tooth structure: A critical review of "micro" bond strength test methods. Dent Mater 2010;26:e50-62.

19. Saber SE, El-Askary FS. The outcome of immediate or delayed application of a single-step self-etch adhesive to coronal dentin following the application of different endodontic irrigants. Eur J Dent 2009;3:83-9.

20. Yoshida Y, Nagakane K, Fukuda R, Nakayama Y, Okazaki M, Shintani $\mathrm{H}$, et al. Comparative study on adhesive performance of functional monomers. J Dent Res 2004;83:454-8.

21. Yoshioka M, Yoshida Y, Inoue S, Lambrechts P, Vanherle G, Nomura Y, et al. Adhesion/decalcification mechanisms of acid interactions with human hard tissues. J Biomed Mater Res 2002;59:56-62.

22. Yildirim S, Tosun G, Koyutürk AE, Sener Y, Sengün A, Ozer F, et al. Microtensile and microshear bond strength of an antibacterial self-etching system to primary tooth dentin. Eur J Dent 2008;2:11-7.

23. Ercan E, Erdemir A, Zorba YO, Eldeniz AU, Dalli M, Ince B, et al. Effect of different cavity disinfectants on shear bond strength of composite resin to dentin. J Adhes Dent 2009;11:343-6.

24. Fawzy AS, Amer MA, El-Askary FS. Sodium hypochlorite as dentin pretreatment for etch-and-rinse single-bottle and two-step self-etching adhesives: Atomic force microscope and tensile bond strength evaluation. J Adhes Dent 2008;10:135-44.

25. Inaba D, Ruben J, Takagi O, Arends J. Effect of sodium hypochlorite treatment on remineralization of human root dentine in vitro. Caries Res 1996;30:218-24.

26. Semeraro S, Mezzanzanica D, Spreafico D, Gagliani M, Re D, Tanaka T, et al. Effect of different bur grinding on the bond strength of self-etching adhesives. Oper Dent 2006;31:317-23.

27. Yiu CK, Hiraishi N, King NM, Tay FR. Effect of dentinal surface preparation on bond strength of self-etching adhesives. J Adhes Dent 2008;10:173-82.

28. Santos JN, Carrilho MR, De Goes MF, Zaia AA, Gomes BP, Souza-Filho FJ, et al. Effect of chemical irrigants on the bond strength of a self-etching adhesive to pulp chamber dentin. J Endod 2006;32:1088-90.

29. Toledano M, Perdigão J, Osorio E, Osorio R. Influence of $\mathrm{NaOCl}$ deproteinization on shear bond strength in function of dentin depth. Am J Dent 2002;15:252-5.

30. Uceda-Gómez N, Reis A, Carrilho MR, Loguercio AD, Rodriguez Filho LE. Effect of sodium hypochlorite on the bond strength of an adhesive system to superficial and deep dentin. J Appl Oral Sci 2003;11:223-8.

31. Tezvergil-Mutluay A, Mutluay MM, Gu LS, Zhang K, Agee KA, Carvalho RM, et al. The anti-MMP activity of benzalkonium chloride. J Dent 2011;39:57-64.

32. Sharma V, Rampal P, Kumar S. Shear bond strength of composite resin to dentin after application of cavity disinfectants-SEM study. 
Contemp Clin Dent 2011;2:155-9.

33. Gürgan S, Bolay S, Kiremitçi A. Effect of disinfectant application methods on the bond strength of composite to dentin. J Oral Rehabil 1999;26:836-40.

34. Stanislawczuk R, Costa JA, Polli LG, Reis A, Loguercio AD. Effect of tetracycline on the bond performance of etch-and-rinse adhesives to dentin. Braz Oral Res 2011;25:459-65.

35. Fawzi EM, Elkassas DW, Ghoneim AG. Bonding strategies to pulp chamber dentin treated with different endodontic irrigants: Microshear bond strength testing and SEM analysis. J Adhes Dent 2010;12:63-70.

\begin{tabular}{|l|l|}
\hline \multicolumn{2}{|c|}{ Access this article online } \\
\hline Quick Response Code: & Website: \\
\hline & www.eurjdent.com \\
\hline & Source of Support: Nil. \\
\hline
\end{tabular}

